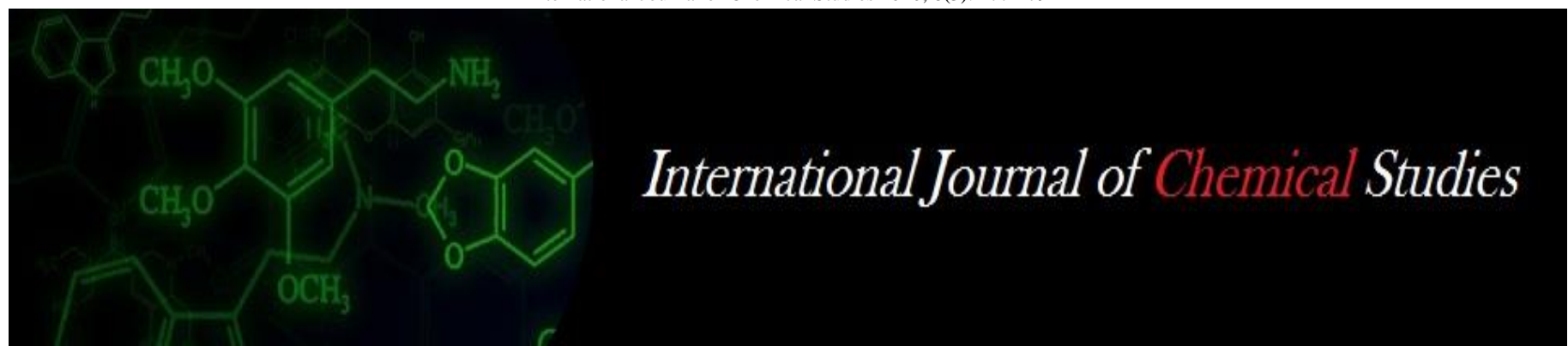

P-ISSN: 2349-8528

E-ISSN: 2321-4902

www.chemijournal.com

IJCS 2020; 8(3): 277-279

(C) 2020 IJCS

Received: 28-03-2020

Accepted: 30-04-2020

\section{RL Vasava}

Department of Agronomy

B.A. College of Agriculture

Anand Agricultural University,

Anand, Gujarat, India

\section{SN Shah}

Department of Agronomy

B.A. College of Agriculture

Anand Agricultural University,

Anand, Gujarat, India

HK Patel

Department of Agronomy

B.A. College of Agriculture

Anand Agricultural University,

Anand, Gujarat, India

\section{JC Shroff}

Department of Agronomy

B.A. College of Agriculture

Anand Agricultural University,

Anand, Gujarat, India

Corresponding Author:

RL Vasava

Department of Agronomy

B.A. College of Agriculture

Anand Agricultural University,

Anand, Gujarat, India

\section{Effect of nutrient management through organic sources on quality, post-harvest soil nutrient and economics fenugreek (Trigonella foenum-graecum L.)}

\author{
RL Vasava, SN Shah, HK Patel and JC Shroff
}

DOI: https://doi.org/10.22271/chemi.2020.v8.i3d.9241

\section{Abstract}

The beneficial role of supplemented organic manures and bio-fertilizers in improving soil physical, chemical and biological role is well known, which in turn helps in better nutrient absorption by plants and resulting higher yield demonstrated. A field experiment conducted at College Agronomy Farm, Anand Agricultural University, Anand (Gujarat) to study the effect of nutrient management through organic sources in fenugreek (Trigonella foenum-graecum L.) during 2016-17. There were total ten treatments with four replication tested under Randomized Block Design. Result revealed that application of vermicompost@1.0 t/ha recorded significantly higher seed and straw yield. Significantly higher organic carbon and available soil nutrient status were observed with the treatment Compost @ $1.5 \mathrm{t} / \mathrm{ha}+$ Vermicompost @0.5 t/ha while, Vermicompost @0.5 t/ha + Bio NP (Rhizobium and PSB) recorded higher benefit cost ratio.

Keywords: Nutrient management, soil nutrient, economics fenugreek, Trigonella foenum-graecum

\section{Introduction}

Fenugreek is the third largest important seed spice in India (after coriander and cumin). Fenugreek is one of the oldest cultivated plant and it was a part of Indian diet even 3000 years ago. Fenugreek seeds are rich in essential amino acids and trigonelline for which it is valued for medicinal uses. A potential use of fenugreek is for extraction of sapogenin and diosgenin (a steroid precursor) which are used as oral contraceptives and for production of corticosteroid. Nutrient supply through organic manures can fulfill the need of crop as fenugreek required lower amount of nutrients. Application of organic manure like compost, vermicompost, castor cake, bio fertilizer alone or in combination improves soil fertility, growth and yield of fenugreek. The application of organic sources of nutrients viz, castor cake, compost, vermicompost, Bio NP reduce the dependence on chemical inputs and it not only acts as a sources of nutrients but also provides micronutrient as well as modifies the soil physical behaviour and increases the efficiency of applied nutrients. Looking to this, present experiment "Nutrient management through organic sources in fenugreek (Trigonella foenum-graecum L.) under middle Gujarat condition planned.

\section{Materials and Method}

A field experiment was conducted at College Agronomy Farm, Anand Agricultural University, Anand to study the effects of "Nutrient management through organic sources in fenugreek (Trigonella foenum-graecum L.)" during the year 2016-17. Ten treatments comprising of nutrient management viz., $\mathrm{T}_{1}$ : No manures (Control), $\mathrm{T}_{2}$ : Compost @ $2.0 \mathrm{t} / \mathrm{ha}$, $\mathrm{T}_{3}$ :Vermicompost @ 1.0 t/ ha, $\mathrm{T}_{4}$ : Castor Cake @ $0.5 \mathrm{t} / \mathrm{ha}, \mathrm{T}_{5}$ : Bio NP (Rhizobium and PSB), $\mathrm{T}_{6}$ : Compost @1.5 t/ha + Bio NP (Rhizobium and PSB), $\mathrm{T}_{7}:$ Vermicompost @ $0.5 \mathrm{t} \mathrm{ha}^{-1}+$ Bio NP(Rhizobium and PSB), T : Castor Cake @ 0.25 t/ha + Bio NP (Rhizobium and PSB), $\mathrm{T}_{9}$ : Compost@1.5 t/ha+Vermicompost@0.5 t/ha, T 10 : Compost@1.5 t/ha+Castor Cake@ $0.25 \mathrm{t} / \mathrm{ha}$ were tested in randomized block design with four replications. The soil of the experimental field was sandy loam (locally known as Goradu soil); slightly alkaline in nature (pH 7.89) with good drainage and fair moisture retention capacity. The experimental soil was low in organic carbon $(0.48 \%)$ and available nitrogen $(210.50 \mathrm{~kg} / \mathrm{ha})$, medium in available 
phosphorus $(32.57 \mathrm{~kg} / \mathrm{ha})$ and fairly high in available potassium (312.06 kg/ha). Gujarat fenugreek 2 (GF 2) was selected for the present investigation. Bio NP (Rhizobium and PSB) applied @ 1.0 lit ha $^{-1}$ with organic sources except in treatment $\mathrm{T}_{5}$. Compost prepared through chimney composting method at Agronomy Farm was used. Organic manure was analysis before used for individual treatment and content is given below Table. From the net plot area collected seed yield and converted into hectare. The Protein content of the seed was calculated by multiplying percent nitrogen content in seed with the factor 6.25 (A.O.A.C., 1960). Organic carbon in soil was determined by Walkley and Black method (Jackson, 1973) [2]. Available nitrogen in soil was determined by Alkaline Permanganate method, Available phosphorus in soil was determined by Olsen's method by Jackson (1973) ${ }^{[2]}$. Available potassium in soil was determined by flame photometer method (Jackson 1973) ${ }^{[2]}$. The chemical analysis for seed and soil samples carried out by various standard methods. The data were analyzed individually as peer the standard analysis of variance ANOVA technique using the Randomized Block Design (Factorial). The treatment comparisons were made using $\mathrm{t}$ test at $\mathrm{P}=0.05$ level of significance.

Nutrients content in inputs:

\begin{tabular}{|c|c|c|c|c|c|c|c|c|}
\hline \multicolumn{2}{|c|}{ Vermi compost (\%) } & \multicolumn{3}{c|}{ Compost (\%) } & \multicolumn{4}{c|}{ Castor cake (\%) } \\
\hline $\mathrm{N}$ & $\mathrm{P}_{2} \mathrm{O}_{5}$ & $\mathrm{~K}$ & $\mathrm{~N}$ & $\mathrm{P}_{2} \mathrm{O}_{5}$ & $\mathrm{~K}$ & $\mathrm{~N}$ & $\mathrm{P}_{2} \mathrm{O}_{5}$ & $\mathrm{~K}$ \\
\hline 1.81 & 1.01 & 0.84 & 0.85 & 0.15 & 0.50 & 3.72 & 1.50 & 1.08 \\
\hline
\end{tabular}

\section{Result and Discussion}

The seed and straw yields being functions of growth and yield attributes improved significantly due to the cumulative effect of these attributes. All growth parameter and yield parameters had higher values recorded for treatment $\mathrm{T}_{3}$ (Vermicompost @ $1.0 \mathrm{t} / \mathrm{ha}$ ), being at par with treatments $\mathrm{T}_{7}$ and $\mathrm{T}_{9}$. Similar trend was followed for seed yield and significantly higher seed yield (2245 kg/ha) was recorded with treatment $\mathrm{T}_{3}$, followed by $\mathrm{T}_{7}(2190 \mathrm{~kg} / \mathrm{ha})$ and $\mathrm{T}_{9}(2053 \mathrm{~kg} / \mathrm{ha})$. The beneficial effect on yield attributes might be also due to increased supply of all the essential nutrients by vermicompost which might have resulted in higher assemble of food and its subsequent partitioning to sink. The findings of present investigation are supported by those of Sahu et al. (2014) ${ }^{[3]}$. Application of vermicompost @ 1 t/ha along with bio NPK significantly increased yield attributes and yield. Bio-fertilizers add nutrients through the natural processes of nitrogen fixation and stimulating plant growth through synthesis of growth promoting substances and might have positively influenced on the crop yield.

The data pertaining protein content $(\%)$ in seed influenced by different nutrient management practices are presented in Table-1. It was revealed from the data that protein content of fenugreek seed was remained unchanged due to application of different nutrient management treatments and they did not exert any significant influence on protein content. However, numerically higher protein content of $23.35 \%$ was obtained in the treatment $\mathrm{T}_{3}$ (Vermicompost @ $1.0 \mathrm{t} / \mathrm{ha}$ ). This might be due to absorption of equal amount of nitrogen in all nutrient management treatments.
Further results (Table-1) indicated that nutrient management practices have significant influence on organic carbon content of the soil (Table-1). Significantly higher organic carbon $(0.54 \%)$ was observed under treatment $\mathrm{T}_{9}$ (Compost @ 1.5 t/ha+ Vermicompost @ 0.5t/ha). This might be due to the beneficial effect of organic manures on organic carbon content could be attributed to the presence of Bio NP and enhanced microbial activities.

Significantly higher available nitrogen of $229.02 \mathrm{~kg} / \mathrm{ha}$ was observed under treatment $\mathrm{T}_{9}$ (Compost @ $1.5 \mathrm{t} / \mathrm{ha}+$ Vermicompost @ 0.5t/ha) being at par with $\mathrm{T}_{2}$ and $\mathrm{T}_{3}$. The lower amount of available nitrogen (188.16 kg/ha) was observed under treatment $\mathrm{T}_{1}$ (No manures). This might be due to reduced nutrient loss when organic and bio-fertilizers were applied in combinations which improved the availability of soil nutrients. Similar result was obtained by Patel et al. (2013). Organic manure has got some solubilizing effect on some mineral compounds present in soil and brings about the conversion of a number of chemical elements in available form. The beneficial effect of organic manures on organic carbon content could be attributed to the presence of higher organic matter and enhanced microbial activities. Patel et al. (2014) ${ }^{[4]}$, Verma et al. (2014) ${ }^{[6]}$ and Naher et al. (2016) ${ }^{[5]}$ also recorded improvement in soil fertility after crop harvesting owing to integrated nutrient management.

Data presented in Table-1 revealed that effect of nutrient management practices on available phosphorus in the soil was significant at harvest. Significantly higher available phosphorus $(37.07 \mathrm{~kg} / \mathrm{ha})$ was observed under treatment $\mathrm{T}_{9}$ (Compost@1.5 t/ha + Vermicompost @ 0.5 t/ha) being at par with $T_{2}, T_{3}$ and $T_{5}$. This might be due to organic manures on decomposition solubilize insoluble phosphorous fractions through release of various organic acids and increase available phosphorous status in soil. It also forms chelates with essential plant nutrients and fixation of elements which favours availability of nutrient to the crop (Patel et al. (2014) [4]. The improvement in soil fertility after crop harvest due to integrated nutrient management was also reported by Verma et al. (2014) ${ }^{[6]}$ in fenugreek.

Perusal of data presented in Table-1 indicated that available potassium content $(326.92 \mathrm{~kg} / \mathrm{ha})$ in the soil after experimentation of fenugreek crop was not significantly influenced due to different sources of nutrient management. However, numerically higher amount of potassium content was observed under the treatment $\mathrm{T}_{9}$ (Compost @ $1.5 \mathrm{t} / \mathrm{ha}+$ Vermicompost @ $0.5 \mathrm{t} / \mathrm{ha}$ ). The non-significant influence of potassium content in the soil might be due the higher amount of potassium in the soil. So different nutrient management treatments failed to exert significant difference in potassium content in the soil.

Economic of fenugreek presented in Table-1 revealed that the highest net realization of ₹65474/ha was incurred with application of treatment $\mathrm{T}_{7}$ (Vermicompost @ $0.5 \mathrm{t} / \mathrm{ha}+\mathrm{Bio}$ NP (Rhizobium and PSB) and followed by treatment $\mathrm{T}_{3}$ (Vermicompost @ 1.0 t/ha) with net realization of ₹64652/ha. The lowest net realization of ₹37560 ha ${ }^{-1}$ was recorded under the treatment $\mathrm{T}_{2}$ (Compost @ $2.0 \mathrm{t} / \mathrm{ha}$ ). In case of benefit cost ratio, the highest benefit cost ratio of 3.70 was recorded in treatments $\mathrm{T}_{7}$ (Vermicompost @ $0.5 \mathrm{t} / \mathrm{ha}+$ Bio NP (Rhizobium and PSB) Treatment $\mathrm{T}_{2}$ registered the lowest benefit cost ratio of 2.49 as compared to other treatments. 
Table 1: Effect of organic nutrient sources on quality, soil nutrient content and economics of fenugreek

\begin{tabular}{|c|c|c|c|c|c|c|c|c|c|c|c|}
\hline \multirow[b]{2}{*}{ Treatment } & \multirow{2}{*}{$\begin{array}{c}\text { Protein } \\
\text { content }(\%)\end{array}$} & \multirow{2}{*}{$\begin{array}{c}\text { Organic } \\
\text { carbon }(\%)\end{array}$} & \multicolumn{5}{|c|}{ Available soil nutrient (kg/ha) Yield (kg/ha) } & \multirow{2}{*}{$\begin{array}{c}\text { Gross Income } \\
\left(\mathrm{ha}^{-1}\right)\end{array}$} & \multirow{2}{*}{\begin{tabular}{|c|c|} 
Gross \\
Expenditure $^{-1}$ \\
$\left(\right.$ ha $\left.^{-1}\right)$
\end{tabular}} & \multirow{2}{*}{$\begin{array}{c}\text { Net } \\
\text { Realization } \\
\left(\mathbf{h a}^{-1}\right)\end{array}$} & \multirow[b]{2}{*}{ BCR } \\
\hline & & & $\mathbf{N}$ & $\mathbf{P}_{2} \mathrm{O}_{5}$ & $\mathrm{~K}_{2} \mathrm{O}$ & Seed & Straw & & & & \\
\hline $\mathrm{T}_{1}$ & 21.95 & 0.44 & 188.16 & 30.50 & 303.29 & 1443 & 3246 & 59343 & 20594 & 38749 & 2.88 \\
\hline $\mathrm{T}_{2}$ & 22.67 & 0.53 & 217.76 & 36.79 & 321.71 & 1524 & 3508 & 62714 & 25154 & 37560 & 2.49 \\
\hline $\mathrm{T}_{3}$ & 23.35 & 0.51 & 212.22 & 35.73 & 315.85 & 2245 & 4572 & 92086 & 27434 & 64652 & 3.36 \\
\hline $\mathrm{T}_{4}$ & 22.62 & 0.46 & 208.88 & 32.76 & 319.74 & 1722 & 3780 & 70770 & 26009 & 44761 & 2.72 \\
\hline $\mathrm{T}_{5}$ & 22.65 & 0.45 & 206.75 & 35.16 & 304.19 & 1880 & 3849 & 77125 & 20867 & 56258 & 3.65 \\
\hline $\mathrm{T}_{6}$ & 22.47 & 0.47 & 203.76 & 33.23 & 322.95 & 1914 & 4078 & 78599 & 24287 & 54312 & 3.24 \\
\hline $\mathrm{T}_{7}$ & 21.67 & 0.48 & 198.49 & 32.49 & 317.98 & 2190 & 4322 & 89761 & 24287 & 65474 & 3.70 \\
\hline $\mathrm{T}_{8}$ & 20.95 & 0.46 & 204.39 & 33.43 & 319.07 & 2031 & 4069 & 83275 & 23545 & 59730 & 3.54 \\
\hline $\mathrm{T}_{9}$ & 21.47 & 0.54 & 229.02 & 37.07 & 326.92 & 2053 & 4296 & 84268 & 27433 & 56835 & 3.07 \\
\hline $\mathrm{T}_{10}$ & 22.90 & 0.49 & 206.82 & 32.70 & 323.48 & 1964 & 4060 & 80590 & 26722 & 53868 & 3.02 \\
\hline $\mathrm{SEm} \pm$ & 0.52 & 0.01 & 6.33 & 1.15 & 6.38 & - & - & - & - & - & - \\
\hline $\mathrm{CD}$ at $5 \%$ & NS & 0.04 & 18.35 & 3.33 & $\mathrm{NS}$ & - & - & - & - & - & - \\
\hline CV \% & 4.67 & 5.73 & 6.09 & 6.75 & 4.02 & - & - & - & - & - & - \\
\hline
\end{tabular}

\section{Conclusion}

For the result of experimentation, it is concluded that application of vermicompost @ 1.0 t/ha fenugreek recorded significantly higher seed and straw yield, protein content. Application of Compost @ 1.5 t/ha + Vermicompost @ 0.5 t/ha reported higher available soil nutrient status. In case of economics returns, application of Vermicompost @ $0.5 \mathrm{t} \mathrm{ha}^{-1}$ + Bio NP (Rhizobium and PSB) reported higher BCR.

\section{Reference}

1. Cochran WG, Cox GM. Experimental designs. John Willey and Sons. Inc., New York, 1957, 546-568.

2. Jackson ML. Soil Chemical Analysis. Prentice Hall of India Pvt. Ltd., New Delhi, 1973.

3. Sahu RL, Hansa S, Sachin K. Effect of application of inorganic fertilizers and biofertilizers on growth components and yield traits of coriander (Coriandrum sativum L.). International $\mathrm{J}$ of Agricultural Sciences, 2014; 10(1):433-436.

4. Patel DM, Patel GN, Patel JC. Nitrogen management in fenugreek (Trigonella foenum-graecum L.) under organic farming. Research on Crops, 2014; 15(2):526531.

5. Naher M, Fahim AH, Wadud MA. Crop productivity and nutrient uptake of fenugreek (Trigonella foenum-graecum L.) as influenced by integrated nutrient management. SAARC Journal of Agriculture. 2016; 14(1):71-79.

6. Verma SR, Shivran AC, Bhanwaria R, Singh M. Effect of vermicompost and sulphur on growth, yield and nutrient uptake of fenugreek (Trigonella foenum- graecum L.). The bioscan. 2014; 9(2):667-670. 